\title{
Elementary School Global Partnership Projects: Are Good Intentions Good Enough?
}

\author{
Sandra Ryan, $\mathrm{PhD}$ \\ Independent Scholar, Calgary \\ seryan@shaw.ca
}

\begin{abstract}
Many Alberta elementary students participate in school global partnerships and projects involving the human rights and wellbeing of people in economically developing countries. These projects are often undertaken in times of disaster, or as a component of developing global citizenship, or as action projects aimed at meeting specific curricular and school district outcomes. This paper summarizes some of the understandings and beliefs of ten Alberta grade six students from two urban schools who had participated in such projects. Generally, students felt they had developed an increased awareness of issues in the developing world, and believed that they were agents of positive change. Other possibly imperialistic perceptions - regardless of project context also emerged. These include that: All developing countries are basically the same, are dependent on wealthier countries to progress towards a more "normal" western life, and that money holds the power to transformation.
\end{abstract}

\section{Introduction}

Noddings' (2005, p. 6) description of deplorable conditions in economically developing countries in terms of high infant mortality rates, hunger, child labour, sweat shops, destruction of natural environments, lack of access to western medications, and deprivation of education is dire. The media provides innumerable images of the developing world as its peoples try to cope with massive historical, systemic inequalities which are exacerbated by natural disasters and conflict. Abdi and Schultz (2008), for example, discuss the billion people who cannot read or write, and the 8-9 hundred million people who lack access to safe and clean water. In such places, citizenship rights continue to be denied rather than achieved (Abdi \&Schultz, 2008, p. 3).

Increasingly, many schools across the province of Alberta participate in global action projects which concentrate on the quality of life and human rights of people in developing countries. Understandably, these projects take a variety of forms, including fundraisers which 
support the work of nongovernmental organizations (NGOs), as well as international school-toschool partnerships. Frequently, these global action projects are initiated during natural disasters. Often, students and school communities are moved to take action by the images and stories presented by the media and humanitarian organizations. In an attempt to alleviate human suffering and provide basic needs to peoples in distress, schools usually respond to calls from humanitarian organizations to become actively involved. It is also possible that the catalyst for a number of such projects is connected to an expanded concern with international and global citizenship education in curriculum which increasingly stresses the importance of active citizenship and participation, universal human rights and social justice, and the development of responsible citizens in the local, national, and global communities (Clemitshaw, 2008; Sears \& Hughes, 1996). Sears and Hughes' (1996) study of Canadian Social Studies curriculum found that, "In the documents, the notion of citizenship is widely seen as extending beyond the community, province, and nation to include important global elements....Most jurisdictions have developed one or more specific programs or courses that would fall under the rubric of global education and aim to develop "responsible world citizens" (quoted in Alberta Education, 1990b, p. 33) (p. 133). As well, Masemann (1987) determined that "the main ideology of citizenship education is the importance of citizen action and participation (p. 5)" (quoted by Sears \& Hughes, 1996, p. 129).

The Alberta Education Social Studies Program of Studies (2005) is no exception to the recent educational policy. Grade six students for instance, should "develop age-appropriate behaviour for social involvement as responsible citizens contributing to their community such as: Demonstrate commitment to the well-being of their community by drawing attention to situations of injustice where action is needed" (Alberta Education Social Studies, Grade Six, p. 7). Alberta Grade 3 Social Studies specifically addresses global citizenship and asks students to consider: "In what ways can individuals and groups contribute to positive change in the world?" (Alberta Education Social Studies, Grade 3, 2005, p. 5). The desire to develop informed and involved citizens in schools is also prevalent in the goals and directives for several Alberta school districts. It is quite common to read outcomes referring to students becoming informed, involved, responsible citizens in the global community who are able to address issues of social justice $^{1}$. 
The proliferation of outcomes, global classrooms, and global citizenship projects demonstrates the value that is placed upon such learning experiences. And who can argue such laudable goals? Pike and Selby (1999) have described the aims of the global classroom: "The global classroom is, by definition, futures-oriented. Global educators seek to promote cooperation, equity, social justice and respect for all living things as a means of creating a better tomorrow....students can be encouraged to take steps to realize those futures through schoolbased social, political and environmental action projects" (p. 218). Likely most would agree with this comprehensive description; however, major challenges include how each of these concepts is understood by individual educators and students, what assumptions are held concerning global projects, and how the global action projects are designed, implemented and evaluated.

This paper is developed specifically for the Special Issue. It discusses the unanticipated findings from a far larger research project in which students' voices were valued and validated, as they reflected upon their global action projects ${ }^{2}$. The paper presents some key student perceptions of developing countries from the larger study. As importantly, it reveals some specific, unexamined elements of power and position which appeared to exist in the projects. It also discusses another surprise concerning colonial threads which are perhaps unconsciously woven into northern global action projects, and in effect, such projects reinforce stereotypical, imperialistic perspectives of the developing and developed world. Furthermore, that such stereotypes are largely unexamined within the context of some global action initiatives for elementary students is revealed; hence the title of this paper.

\section{Student Perceptions of Developing Countries: A Singular Perspective}

Most people that don't know much about Africa think that everyone here is black, and that animals run around in the streets. In other words they generalize. A lot of people think that we aren't well educated but we are! (Paulus; grade six, How does basic education help to build and sustain our communities? 2006, Namibia $^{3}$ )

Significantly in the 2011 study, perceptions of developing countries held by students were very similar regardless of partner country, project context, and project type. Indeed, when describing developing countries, participants almost always excluded specific elements of the partner country in favour of massive generalizations about places in which major school fundraising activities had occurred (primarily Haiti and the African continent). Students 
discussed media representations, and summarized information from children's literature in classes $^{4}$. Although some students realized they were presenting generalizations, and even explained their thinking processes in this regard, they did not demonstrate any awareness that such generalizations might be problematic when learning to understand another's perspective.

I have seen pictures of people that live maybe not in [the African country] but like Africa or something, and they don't have very good conditions, so you could kind of take what Africa has and what [the African country] has and just kind of go like, okay, maybe they have something in between or maybe they have something like, you know, you can compare. (Interview, C1:11)

The most commonly presented perception of developing countries was that of neediness and that lives had not yet advanced to being "normal", meaning achieving a Canadian standard. Specific issues identified were lack of access to clean water and sanitation, food, medications, shelter, and education. In this sense the students supported Noddings' description cited earlier.

Well, like when you see them, kids are on the streets and they don't have any shoes on, and you know, that's just, it's not normal. Like, like, we have all those things, so you know it's developing when you see that kind of stuff. And they say that they don't have enough to eat those days. And then there's like, like in Afghanistan, like the Taliban are there and there's like, gunfires everywhere. So that's what, that's how I'd, I'll kind of describe it - with like, just terrible things going on everywhere. (Interview, K1:13)

Lots of people in you know in a country like that you know suffer from cholera disease....lots of people are dying from hunger too. (Interview, B1:2)

References to abnormal living conditions in developing countries were frequent: "They don't have bricks to build the normal houses yet" (Interview, Jo2:5); "They probably thought that was like normal water that they were drinking" (Interview, T2:2). Stories appeared to demonstrate that the students' everyday, middle class, urban life, is understood to be the norm from which all others are judged. Pike and Selby's (1999) research into perspectives consciousness reminds us that we use our own frameworks to view the world. But this matter of understanding one's own perspective and learning to see and value that of another was not evident in student stories. Examining perspectives and the imagination of the normal is an important aspect of global projects in order that teachers help students to recognize different perspectives, stereotypes, and the process of othering. Students need assistance in identifying and 
examining which types of people determine what is considered to be normal, where the students are positioned in the social and economic hierarchy, and who is self and who is other (Pieterse \& Parekh, 1995; Seixas, 2006; Willinsky, 1998).

However confident students were as they described conditions in developing countries, they became substantially less so when asked to consider more specific questions about life in these places. Students did not present a historical perspective in explanations regarding how the countries had come to be in such dire circumstances, beyond people coping with the effects of natural disasters. Nor were students aware as to whether or not these circumstances applied to all citizens of a developing country, or whether circumstances differed significantly depending upon urban, rural, or socio-economic contexts. Dire conditions were assumed to have always existed, for some countries. Students did not indicate that they had explored root causes of underdevelopment.

I'd like to say that some basically third world countries, especially I believe, Africa, I'd have to say is one of the ones that has been like this for quite a long time as far as I know. (Interview, E1:11)

Most of the participants referred to education as a primary issue for peoples in developing countries. Students understood that education is a matter of great importance and is especially lacking, in both formal and non-formal social contexts in economically developing countries.

We need to be sending them education, especially education on how to survive in third world countries because they have like lots of resources and they're um, pretty much destroyed. Most of these third world countries, like almost like Brazil, Brazil isn't much of a third world country but it's pretty poor and well they're cutting down their rainforest which is a big resource. And they're cutting all these trees to make their farms. Well, it's not really their fault because they're trying to make a living - they don't know any better - but then we need to teach them to know better not to cut down these forests or we're going to lose all our oxygen. (Interview, E1:3)

It was interesting to note that generally, the Canadian students' generalizations usually blamed the people in the south for deforestation in the Amazon's tropical rain forest, and the resultant loss of oxygen globally. They were likely unaware that much of the large scale deforestation globally, as in the north, is often attributed to the industrial development actions of multinational/transnational northern companies. 
Suggested also was that there are very few in developing countries who would be able to teach their own people, thus the need for "us" to intervene.

And of course there's not many educated people anyways so who's going to teach anyways? Who's going to teach them? (Interview, E1:9)

Some students felt that the solution may be to send our teachers "there" to provide training or to bring people "here" to be trained. Surprisingly, such statements were not unlike missionary models of the past. There was very little to no discussion of Indigenous knowledge and its value, or of the variety of educational opportunities which might exist in southern countries. Without problematizing these matters with school children, it is possible the idea of the "civilizing mission" still lingers.

Also surprising, because students reported researching information concerning the partner countries, was that there appeared to be little understanding as to whether or not these countries have large cities, airports, cars and access to new technologies. Some students stated that there could be no airports, since they had not seen them in the information studied in school.

Generally, it was understood that "only the very top, rich people" (Interview, B1:15) had cars. They thought that most people used dirt roads and paths for walking and biking. "They have to find some small paths for foot" (Interview, Jo2:5).

Their big city in developing countries would be like, there'd be a lot of people there but it wouldn't have skyscrapers or like really nice houses, or like sports clubs, or hockey rinks, They would just sort of be um, they'd have like houses but it wouldn't be homes that we live in. (Interview, T2:6)

As importantly, students felt that communications technologies are definitely lacking and especially in the African continent, few would even have phones.

They don't really have access to iphones, or ipods, or WiFi there. (Interview, T2:7)...But you like, got to keep in mind, over there it's; like the [country], or like Pakistan, or Afghanistan, or something like that, they don't really have all that technology. They can't really call each other up or be on the Xbox talking to each other. Like, they don't really have a way to interact with each other. (Interview, T2:16).

Interestingly, the students seemed to think that economically developing countries lack for example: (i) the types of infrastructure and man-made buildings for urban/rural designed, planned, and constructed environments; (ii) the wide range and types of communications and 
technology; and (iii) the human, material, and financial resources usually associated with the economically developed north. There is accordingly, little understanding and realization, on the part of the students, and perhaps their teachers, that well developed and organized civilizations existed and often preceded the intrusion of empire, which effectively caused dismantling of those civilizations. More recent colonial intrusions, and post World War II efforts towards development, might well have heightened existing inequalities and imbalances within and between regions and countries.

Confounding to students, was the consideration of how those working in developing countries - representatives of NGOs, and school liaisons - would travel there and communicate with people in the country, if it was assumed these technologies and transportation options did not exist. In light of this discussion, several students thought that perhaps some infrastructure was present, but not much.

Above all else, was the shared assumption that developing countries were unable to progress on their own and required assistance from the west in order to move forward. Stories possessed echoes of modernization theory and "The Legend of the Big Push" (Easterly, 2006).

They sort of like, need to like sort of go step by step and like try to follow what we've done so far and maybe make adjustments to make it even better than what we have right now. (Interview, T2:7)

We are just kind of opening our eyes and starting to give the countries that aren't quite finished developing a little bit of a push. (Interview, C1:12)

And although people in developing countries might try, they will find that being as wealthy as those in the west might remain just out of reach.

It's almost impossible to get as rich as us. It doesn't mean we can't try you know, to make, to help them to stretch themselves by trying. (Interview, B1:16).

Importantly, when very specific questions were posed of the students, they began to question their assumptions and their rather common sense perceptions of developing countries. Students indicated that perhaps, in spite of their heightened global awareness, they were not really that well-informed about the daily circumstances of their global partners and the countries in which they lived. Interestingly, students had not conducted additional research beyond what was presented in class and reported that information about their partner country was often lacking in the media. Students felt that dialoguing with students in their partner schools would 
have been a preferred method of learning about each other and of great benefit to their projects and understanding. This was considered especially important as participants presented their beliefs about how difficult it is for anyone to know another person from a country so far away.

I think it's really hard for us because we don't have no idea how their lifestyle is, so can't happen - just a little bit. (Interview, T2:4)

They don't really have the option to go to other countries and look at what they are living like...they're stuck in their country that [they] love so much. (Interview, N2:17)

Regardless of source information, the emphasis placed upon fundraising activities suggested that messages and especially images from the media and humanitarian organizations may have been particularly powerful factors in shaping student perceptions. This is indeed significant, as images from the media and humanitarian organizations generally depict one particular view of developing countries. Furthermore, the countries tend to be shown in very negative, emotive, and incomplete terms (Alam, 1994; Cate, 1994; Glasgow Media Group, 2000; Greene, 2005). News reports and accompanying images tend to focus upon the extraordinary, devastating events occurring in the nations such as earthquakes, war, famine, and disease. Such representations may lead to perceptions of the countries as places in constant turmoil and unable to progress. These images suggest that agency rests with the north and that there is only one model for economic development; an extrapolation of Adichie's thesis of a single story, discussed later. As global action projects are often initiated in times of crisis or natural disaster, the manner in which the media presents images of people in developing countries must be subjected to critical examination in the classroom and explored with students. Providing more accurate explanations for events and images is necessary for people in western countries to understand better what they think they see. Without the accompanying explanations, there can be a tendency to resort to colonial beliefs about the countries being represented, and an acceptance of the traditional, stereotypical imperialistic images as being reality.

The legacy of 500 years of Western expansion, including 200 years of Western hegemony, reflected in racism and exotism, continues to be recycled in Western cultures in the form of stereotypical images of 'non Western' cultures.... Images function as signals and markers in constituting boundaries between self and other, us and them, normal and abnormal. (Pieterse \& Parekh, 1995, p. 4-5) 
From this study, it can be seen that students may need additional guidance to examine how images and the imagination can perpetuate a single, often negative perspective of the other. Furthermore, there is the need to explore concepts and attitudes in the frames of reference which might encourage unquestioning acceptance of media images. For the student participants, media images were accepted entirely at face value. A familiar message of orientalism was repeated continuously; "Orientals were almost everywhere nearly the same” (Said, 1979/2004, p. 38).

\section{Perceptions of Positioning and Power}

Revealed in all student stories, was a distinction between "we" and "them". The dominant perception was that we in the west provide help for them; namely, those less fortunate in developing countries. As clear as the distinction was, the roles appeared to be somewhat confused. "We" was never presented as a group of elementary school fundraisers from afar. Indeed, with strong connotations of the colonial model, we are presumed to be prominent actors in specific physical actions taken on the ground in the south.

We fixed up an entire school....we actually got enough money down that we were able to hire another teacher...we kind of kept the school going I guess you could say and got it restarted as well. (Interview, E1: 8)

We built them classrooms. We've also done [a] roof job like I told you. We've also done water you know, so we like made the water fountains for them....We got them books. (Interview, D1:13)

We made a water well there for clean water" (Interview, K1:3) and "We got the school's library bigger and more books in it. (Interview, K1:8)

Undoubtedly, the students' language is quite troublesome. The students usually positioned themselves as the primary change agents in the schools. Unfortunately, project contributions of southern global partners were seldom, if ever, recognized. To the contrary, when asked directly who represented "we," students suggested themselves, friends of the project liaison who had travelled to the school, and those in the Alberta school community. There was also no indication in the clarification of we, that students' positions of dominance in project roles was re-examined in classroom and school discussions. Accordingly, students assumed that their understanding of the centrality of their roles was correct. 
Easterly (2006) refers to the patronizing aspect inherent in the term "we." He states that this is generally not done in a conscious, deliberate way, nor by all who work with developing countries, but "anytime you hear a Western politician or activist say "we," they mean "we whites" - today's version of the White Man’s Burden” (Easterly, 2006, p. 26). Easterly's statement appears applicable to the student stories and perceptions, suggesting that it is critical for schools to examine "we" when planning, engaging in, and evaluating global projects. Through a careful deconstruction of roles, students are likely to learn that "we" is much larger than themselves. As importantly, any project aimed at creating change in another place usually demands the inclusion and application of skills and knowledges of the country's citizens to achieve the desired end. It might also make more visible, capable, and human, the vital roles of the developing country partner.

Looking to the Alberta curriculum we read, "Social participation skills enable students to develop effective relationships with others, to work in cooperative ways toward common goals and to collaborate with others for the well-being of their communities" (Alberta Education, K-12 Social Studies Program Rationale and Philosophy, Grade 6, 2005, p. 9). It was clear that collaboration, to a large extent, occurred here as classes planned, raised money, and celebrated together. However, those whose lives were to be directly affected by the actions were seldom presented as part of the collaborative effort. Freire (1974/2008) explains the importance of dialogue and collaboration and states that communication is the only path to actual development and transformation. Communication does not allow for people to be objectified - they are subjects acting upon their world in order to create and transform their reality. Reciprocity is essential to communication. The exclusion of partner voices in planning and project discourse, and the lack of reciprocity likely had an impact on creating the "we-them divide" so prevalent in this study and the perception of global action as uni-directional. Abdi and Shultz (2008) suggest:

Any project that aims to achieve inclusive human rights has to be a collaborative one with groups and individuals seeing the protection of others as their own protection. That collaborative effort should also involve human beings learning together and from each other. (Abdi \& Shultz, 2008, p. 5)

Prominently featured in the global partnership projects undertaken by students in this study, was the aspect of planning and the power inherent in the process. Planning for solutions to the problems of the other has long been the work of imperialism and international development. 
Britain's nineteenth century slogan to bring progress to Egypt, "Intervention, Reform, Withdrawal" (Chomsky, 1966/2008), was such an example. Freire (1974/2008) refers to the planning of experts for the other as "extension": Planners assume they know the problem, then create and impose solutions on others, without providing opportunities to dialogue about the problem and devise solutions together. Easterly (2006) suggests that planners think they are already in possession of the answers, determine what to supply, and follow similar blueprints for all. In this study, it appears that the schools and students were very much in the role of planner and that the voice of the partner was silent or marginal at best. It may have been that there were contributions made by partners, but students did not appear to have any knowledge of this. One student remarked that she was not entirely sure "what...things...were going on behind the scenes....I don't think they mentioned it to us" (Interview, C1:3). Suggestions were offered as to why the planning role was extremely important and must be adopted by people in the north:

They don't really know what they have done wrong; they know, they don't know what real life is. (Interview, N2:14)

In introductory discussion about global projects in general, all participants had stated that considering both the positive and negative consequences of global actions is an important step in the planning process and should occur before making decisions about action. Indeed, one participant likened global action to undertaking science fair projects. "You want to have background research before you start.... think you got to know what you're getting into" (T2:9). This would, on the surface, be in agreement with Easterly (2006), Freire (1970/2009) and Moyo (2009) who state that we should do no harm through our actions and should not simply engage in activism without the intellectualizing. This must be thoughtful work that considers our accountability to real human beings in real life circumstances and that we do not have the right to act without considering how we may negatively impact the other. Yet the stories recounting the projects suggested otherwise. None of the participants recalled ever determining and weighing the possible consequences of their actions prior to, during, or upon completion of the project as the work was understood as helpful and based on good intentions. What could possibly be wrong?

Oh, there is nothing wrong with this. We are just doing good things. I guess now, if I were to think about it more deeply, and we were to really get into it, then I would probably realize there was probably a few negative things that could result of this. (Interview, $\mathrm{N} 2: 12)$ 
I don't really think there's a lot of negative consequences because you are doing something good...We didn't really want to focus on that stuff; we wanted to focus on the positive stuff. (Interview, $\mathrm{K} 1: 3)$

As students had opportunity to consider more deeply, positive and negative consequences of their particular actions, they felt somewhat taken aback and determined that likely the consideration of consequences of action prior to engaging in any action - especially direct conversation with global partners - should have taken place. All felt that this is an aspect of the planning that they would be certain to implement in the future.

Above all, the students understood money as essential to any global action with economically developing countries. This appears to be because of the perceived power of donor dollars to create what is seen as better circumstances for those living in these countries and the belief that without money, change is impossible. This perception of money being at the core of action with developing countries may have been enhanced due to the focus of the projects in this study, which was perceived by the students as raising money for specific issues more so than learning about and with others and sharing ways of life. As one student aptly stated, "Maybe it wasn't totally about learning, but like it was basically just about helping too" (Interview, C1:2).

Quite profoundly, upon direct questioning, students could think of no alternative to global action with developing countries beyond fundraising. The two are inextricably linked and it was challenging for them to understand their global projects in any other context. Again, it is possible that this is due to the fact that the primary activity in which students were engaged was raising money; yet, this was not necessarily a new query for all. One of the students shared that her teacher had previously challenged her to come up with other ideas for action but to this day, this is a challenge with which she continues to struggle. There was also no indication provided that the teacher had been able to assist the student with her thinking.

I haven't really come up with a big idea in my head of what else would help because really, it's the money getting supplies for them: It's the money getting all the basic stuff that they need for them. (Interview, K1:15)

The stories did suggest that although there was such a strong focus on money, and students were proud of the amounts raised, what the money had accomplished mattered a great deal more to them. 
If you just raise a bunch of money but you can't do much with the money, that you really can't really do anything, well there is not much point of raising the money. But if you do something with the money, then you can change something. (Interview, Ja2:13)

The ability to change the lives of another for the "better" resonated throughout all stories. Students felt strongly that their efforts and the money raised had the power to transform another's world. They were excited when they were shown pictures of new school rooms and water filters. It was simple really:

If we didn't have the money then their school couldn't change. (Interview, C1:10)

Yet, it appeared that all matters of position and power remained completely unexamined in both projects. Students here had the power to "select" the country which would receive assistance leaving other countries to remain on the list hopeful for a donor. This was seen as a fair process because students had statistics to determine who was most deserving. Students were in the position of determining how funds would be raised and what portion of the proceeds would be given to their country or NGO partner. The money would provide the solution to the problems of the other, but global partners did not have an opportunity to engage in the dialogue. Students also imagined themselves to be the primary actors in building, repair, and procurement of supplies rendering invisible and inconsequential, the contributions of all others involved in the project.

\section{Conclusion}

Of significance in this study, is the perception of sameness of developing countries in spite of school global partners and project contexts being very different. Although the study sample was small, this finding might suggest that it is essential for elementary educators to be far more cognizant of what Adichie (2009) has termed the "danger of a single story". Adichie (2009) suggests that if we "show a people as one thing, and only one thing over and over again, that is what they become." It is possible, in the desire to develop compassionate global citizens through fundraisers following natural disasters and through partnering with those "less fortunate" than ourselves, that schools have presented and reinforced a single story of many peoples. This appears to be supported with the very singular manner in which economically developing countries were described, the lack of meaningful connections in the student participant stories to 
the school's partner countries, and the unanimous and frequent references to Africa as being a country, instead of one of the largest continents on the planet which once had the distinction of being the source of humans, and had some of its oldest civilizations.

The findings in this study would also suggest that the images presented to students and the manner in which projects were undertaken, and their success evaluated, and broadcast to the larger community, have helped to create a shared imagination in the minds of the students and teachers involved that economically developing countries and their peoples are flat, cookie cutter images who lack agency, and the ability to plan and create their own futures.

Slater (2003) describes the imagination or public space as invented and indefinite and a space controlled by its producers. Within this space, producers can manipulate while users passively experience what has been provided for them. Often people are merely spectators and consumers of materials, images, and decisions rather than active participants in the making of the public space. Slater cautions educators about the susceptibility of young people to the public space as they confront it through a set curriculum and activities that have been pre-determined for them with particular aims and goals. As importantly, the media and prescribed school texts determine to a large extent what students are allowed to see. Hopefully, the internet (videos, video-conferencing, blogging) and travel experiences will offer students in the north and south, opportunities to develop increasingly complex, layered, multiple perspectives as they progress through schools, and for many, future post secondary education.

As can be seen, global action projects are not exempt from the public space. This space though, possesses great possibilities for young people and their projects if they are allowed to be equal participants in the process rather than spectators (Slater, 2003, p. 326). Importantly, teachers must also work with students in the production of media and project presentations and help students to identify the ways in which they are representing their global partners.

Elementary students are capable of conducting a far more critical examination of their global actions. Students in this study were asked questions challenging them to think more deeply about project elements beyond the typical "Are you proud?", "What would you do differently?" and "What do you think was the best part of your project?" As they attempted responses to more challenging questions, students realized that their knowledge was perhaps less complete than first thought and that at times, they had acted upon limited and narrow assumptions which were applied to peoples and countries in most continents. Challenge is 
necessary as engaging in "informed and involved global action" is problematic and complex and should not be understood as a simple, well-intended, duty of citizenship. Kincheloe and Steinberg (2002) emphasize the need for examining interpretive practices in the classroom and to understand there are dangers associated with "a problematized body of knowledge being brought in and simply transferred unproblematically to a group of students" (p. 24).

Mundy et al. (2007) suggest in their research that global education is complex due to its wide scope and demanding implementation. Pike (2000) states unequivocally "Few other educational innovations require of practitioners a conscious understanding of all such influences on their lives.[Global education] demands that teacher reflection takes place at unusually sophisticated levels" (p. 70). Andreotti and de Souza (2008) are even more explicit. They state, and here I do justice to their work by quoting them in full, that it is necessary for all to "examine the origins of their own perceptions and cultural logics (their values and assumptions), to develop self-reflexivity, to re-evaluate their own positions" (p. 3). In consideration of this, teachers and students must engage in critical reflection in order to better understand their own assumptions and perceptions and how these affect the ways with which they see the world and choose to act. A greater balance between the negative and positive aspects of life in developing countries should be addressed in order that students here understand that there are multiple ways of living in developing countries, that normal cannot be determined from afar, and that there is joy to be found in different ways of living. Perhaps most importantly, there is a need to understand that the problems that are perceived to exist for those in developing countries are not just problems of that place and those peoples, but are issues with which the developed world has played a significant role in creating and is coping with as well. Students need to understand the interconnectedness of the world; how the actions of people in one place can, and often do, create consequences for those in another. Importantly, students need to develop a greater awareness that these are not problems the north must address for the sole purpose of creating a "better" life for people in the south, but because they are at the core of survival for all on this planet. And although students do appear to be engaging in action with the very best of intentions and are keen to become involved in the world, it must be recognized that informed and responsible action with economically developing countries goes far beyond present fundraising activities, as undoubtedly helpful as they can be. It requires a critical practice if schools are to aim for transformation towards a more just society and more hopeful future for all. 


\section{Notes}

1. Mission and vision statements for major public and Catholic school boards in the province of Alberta indicate goals for students with respect to global action. Examples include:

- $\quad$ "Each student will be a responsible citizen by being an informed and involved member in his or her local, national and global communities." and "Actively contribute to creating a better local and global community." (Calgary Board of Education Annual Monitoring Report Ends 3: Citizenship, 2008, p. 5).

- "All students will be contributors to society and dedicated to the common good." (Calgary Catholic School District Mission and Vision, 2006).

- "Starting with the youngest of our charges, we endeavour to build skills and offer experiences toward a fully realized capacity for compassion and love for all of God's creations with a particular obligation to care for the poor, disenfranchised and lonely people of the world....Charity is vital in the social justice work undertaken by our schools, regardless of grade level....students are aware of and have moved from charity to justice in how they see their responsibilities as advocates of social change." (Edmonton Catholic School District, Social Justice Mandate, 2010).

- $\quad$ "Red Deer Public Schools is responsible for providing the opportunity for our students to acquire the knowledge and skills necessary for become [sic] selfreliant, responsible, caring and contributing members of society." (Red Deer Public School District, District Overview, 2010).

- Fort McMurray Public School District Goal 2.4: "Students model the characteristics of active citizenship." (Fort McMurray School District, Our Goals, 2004-2010)

- "Working collaboratively with community members and groups to increase intercultural appreciation and understanding." as well as "Providing students with outstanding educational experiences that prepare them to be leaders in an evolving global society." (Edmonton Public Schools, District Priorities, 2010).

2. Student voices were presented in a thesis entitled, "Partners in the global community: Global citizens and the best of intentions". For a detailed explanation of the findings and the methodology adopted, see the thesis, held at the University of Calgary (2012).

3. This is an excerpt from a multinational student project (Ghana, Namibia, Canada) entitled How does basic education help to build and sustain our communities? The project was completed in 2006 and shared among the participating schools.

4. Students in both schools recalled reading and being influenced by two books. The first, The Breadwinner, was written by Deborah Ellis and published in 2001. In this fictional story from Afghanistan, the main character, Parvana, impersonates her dead brother to become the family's breadwinner. This is because, as a female in Taliban controlled Afghanistan, she is not allowed to work. The second, Three Cups of Tea, describes the experiences of Greg Mortenson as he builds a school in Korphe, Pakistan. 


\section{References}

Abdi, A.A., \& Shultz, L. (Eds.). (2008). Educating for human rights and global citizenship: An introduction. In A. A. Abdi \& L. Shultz (Eds.), Educating for human rights and global citizenship (pp. 1-9). New York, NY: State University of New York Press.

Adichie, C. (October 7, 2009). Tedtalks: The danger of the single story. Retrieved from http://www.youtube.com/watch?v=D9Ihs241zeg

Alam, S. (1994, May 30). The visual representation of developing countries by developmental agencies and the western media. ZoneZero. Retrieved from http://www.zonezero.com/magazine/articles/shahidul/shahidul.html

Alberta Education. (2005). Grade 6 Social Studies Program of Studies. Retrieved from http://education.alberta.ca/media/774369/ss6.pdf

Alberta Education. (2005). Grade 3 Social Studies Program of Studies. Retrieved from http://education.alberta.ca/media/456082/sockto3.pdf

Andreotti, V., \& de Souza, L.M. (2008). Learning to read the world through other eyes. Educational project hosted by The Centre for the Study of Social and Global Justice. Derby, UK: Global Education. Retrieved from http://www.throughothereyes.org.uk

Cate, F. (1994). Media, disaster relief and images of the developing world: Strategies for rapid, accurate, and effective coverage of complex stories from around the globe. In F. Cate (Ed.), International disaster communications: Retrieved from http://www.annenberg.northwestern.edu/pubs/disas/disas10.html

Chomsky, N. (1966/2008). The responsibility of intellectuals. In A. Arnove (Ed.), The essential Chomsky (pp.39-62). New York, NY: The New Press.

Clemitshaw, G. (2008). Citizenship without history? Knowledge, skills and values in citizenship education. Ethics and Education, 3(2), 135-147. Retrieved from http://www.informaworld.com.ezproxy.lib.ucalgary.ca/10.1080/17449640802439337

Easterly, W. (2006). The white man's burden: Why the west's efforts to aid the rest have done so much ill and done so little good. New York, NY: Penguin Books Ltd.

Freire, P. (1974/2008). Education for critical consciousness. London, GB: Continuum International Publishing Group Ltd.

Glasgow Media Group. (2000). The mass production of ignorance: News content and audience understanding. Retrieved from http://www.gla.ac.uk/Aead/Sociology/media.html

Greene, M. (2005). Teaching in a moment of crisis: The spaces of imagination. The New Educator, 1, 77-80. Retrieved from ERIC database. 
Kincheloe, J.L., \& Steinberg, S.R. (2002). A legacy of Paulo Freire: A conversation. In J. Slater, S. Fain, \& C. Rossatto (Eds.), The Freirean legacy: Educating for social justice (pp. 15 - 26). New York, NY: Peter Lang Publishing, Inc.

Merchant, B. (2010, October 25). Up to $60 \%$ of water wells in developing world don't work (video). Treehugger: Discovery Communications. Retrieved from http://www.treehugger.com/corporate-responsibility/up-to-60-of-water-wells-indeveloping-world-dont-work-video.html

Mundy, K., Manion, C., Masemann, V., \& Haggerty, M. (2007). Charting global education in Canada's elementary schools: Provincial, district and school perspectives. Toronto, CAN: UNICEF. Retrieved from www.unicef.ca/.../EDUCATION/Global_Education_in_Canada_UNICEF_OISE.pdf

Noddings, N. (Ed.). (2005). Global citizenship: Promises and problems. In N. Noddings, (Ed.), Educating citizens for global awareness (pp.1-21). New York, NY: Teachers College Press.

Pieterse, J.N., \& Parekh, B. (1995). Shifting Imaginaries: Decolonization, internal decolonization, postcoloniality. In J.N. Pieterse \& B. Parekh (Eds.), The Decolonization of Imagination: Culture, Knowledge and Power (pp. 1-19). London, UK: Zed Books.

Pike, G. (2000). Global education and national identity: In pursuit of meaning. Theory into Practice, 39(2), 64-73. Retrieved, from ERIC database.

Pike, G., \& Selby, D. (1999). In the global classroom 1. Toronto, ON: Pippin Publishing Corporation.

Said, E.W. (1979/2004). Orientalism. New York, NY: Random House Inc.

Sears, A., \& Hughes, A. (1996). Citizenship education and current educational reform. Canadian Journal of Education, 21(2), 123-142. Retrieved from http://www.cssescee.ca/CJE/Articles/FullText/CJE21-2/CJE21-2-03Sears.pdf

Seixas, P. (2006). What is historical consciousness? In R. Sandwell (Ed.), To the past: History education, public memory, \& citizenship in Canada (pp. 11-22). Toronto, ON: University of Toronto Press.

Slater, J. (2003). Creation of participatory public spaces. In D. Truet, W. Doll Jr., H. Wang, \& W. Pinar (Eds.), The internationalization of curriculum studies (pp. 319-335). New York, NY: Peter Lang Publishing, Inc. Retrieved from ERIC database.

Willinsky, J. (1998). Learning to divide the world: Education at Empire's end. Minneapolis, MN: University of Minneapolis Press. 